\title{
REVISION OF THE POSTED WORKERS' DIRECTIVE: A EUROPEANISATION PERSPECTIVE
}

\author{
Dr Rebecca Zahn*
}

\begin{abstract}
This article places the current legal framework governing posted work within the debate on 'europeanisation' in order to assess to what extent the Posted Worker's Directive may be seen as a successful tool to 'europeanise' national labour law systems as assessed against its dual objectives of promoting the transnational provision of services while also guaranteeing respect for the rights of workers. In doing so, the article contextualises and analyses the Posted Workers' Directive which allows for the identification of remaining gaps in protection. The article concludes with an assessment of the European Commission's most recent proposal to amend the Directive.
\end{abstract}

Keywords: Posted workers, Social dumping, Laval, Europeanisation, free movement of services, workers' rights

Word count (including footnotes): 12,1865

\section{INTRODUCTION}

Recent evidence produced by the European Commission indicates that between 2010 and 2014, the number of workers posted from one EU State to another increased by almost $49 \%$ to a total of approximately 1.9 million workers. ${ }^{1} 86 \%$ of workers are posted to the EU-15 Member States with Germany, France and Belgium receiving the biggest share. Poland, Germany and France accounted for the three largest senders of posted workers in 2014. Postings involve $0.7 \%$ of the total EU workforce although there are wide variations in different sectors. $42 \%$ of total postings occur in the construction sector but posting of workers is also important in the manufacturing industry $(21.8 \%)$, and in other service sectors such as personal services (education, health and social work, 13.5\%) and business services (administrative, professional, and financial services, 10.3\%). It has been estimated that the vast majority of posted workers are male. ${ }^{2}$ It should be noted however that these statistics are far from perfect. The European Commission uses information provided by administrative

\footnotetext{
* Senior Lecturer in Law, University of Strathclyde. The author would like to thank Nicole Busby, Sylvie da Lomba, Dagmar Schiek and the anonymous reviewer for helpful comments on earlier drafts. The usual disclaimers apply.

1 The statistics in this paragraph are drawn from European Commission, Impact Assessment accompanying the document Proposal for a Directive of the European Parliament and the Council amending Directive 96/71/EC concerning the posting of workers in the framework of the provision of services $\operatorname{SWD}(2016) 52$ final, pp 6-8.

2 See Eurofund, Posted workers in the European Union available at http://www.eurofund.europa.eu/observatories/eurwork/comparative-information/posted-workers-in-theeuropean-union.
} 
forms issued by the social insurance authority of the posted workers' country of origin. ${ }^{3}$ But significant gaps arise between national and EU figures and there is a lack of precise data on the duration of posting, the feminisation rate of posted work, the qualifications of the workers and their earnings. Whereas the number of workers who are sent from one Member State - in which they supposedly normally work - to another for a limited period of time has increased sharply; ${ }^{4}$ these so-called 'posted workers' often earn substantially less than local workers for the same work. Moreover, there have been concerns about posted workers being vulnerable to fraudulent activities such as undeclared work practices. ${ }^{5}$

The main relevant regulatory framework has hitherto been the Posted Workers' Directive (PWD) ${ }^{6}$ which came into force in 1996. The PWD has mixed objectives - the promotion of the transnational provision of services within a climate of fair competition while also guaranteeing respect for the rights of workers ${ }^{7}$ - the balancing of which has led to tensions in its interpretation; culminating in the much-debated decision of the Court of Justice of the European Union (CJEU) in Laval $^{8}$ which created a difficult interface between the free movement provisions contained in the Treaty on the Functioning of the European Union (TFEU) and national labour law. The CJEU's decision in Laval has been the subject of a plethora of academic commentary ${ }^{9}$, much of which has concluded that the PWD, in its current form, struggles to adequately balance its objectives of 'guaranteeing respect for the rights of workers' and maintaining 'a climate of fair competition' between local and posted service providers while also promoting 'the transnational provision of services'. As part of its Work Programme 2016 and in recognition of ongoing tensions in the area of posted work, the European Commission published a proposal for a Directive amending the PWD on 8 March $2016 .{ }^{10}$

This article first places the current legal framework governing posted work within the debate on 'europeanisation' in order to assess to what extent the PWD may be seen as a tool to 'europeanise' national labour law systems as assessed against its objective of guaranteeing 'respect for the rights of workers'. A subsequent section identifies remaining gaps in the protection of posted workers. A final section assesses the Commission's most recent proposal against both its objectives and within the context of the europeanisation literature.

\footnotetext{
3 Based on Council Regulation (EU) No 987/2009 [2009] OJ L284/1. See further C Dheret and A Ghimis, 'The revision of the Posted Workers Directive: towards a sufficient policy adjustment?' European Policy Centre Discussion Paper, 20 April 2016, p 4.

4 See note 1 above.

5 Ibid.

6 Directive 96/71/EC concerning the posting of workers in the framework of the provision of services, [1996] OJ L 18/1.

7 Recital 5 of the Preamble to the Directive.

8 Laval un Partneri Ltd v. Svenska Byggnadsarbetareförbundet, Svenska Byggnadsarbetareförbundets avd. 1, Byggettan, Svenska Elektrikerförbundet, C-341/05, EU:C:2007:809.

9 Numerous articles have appeared in the Cambridge Yearbook of European Legal Studies over the years analysing the CJEU's decision in the so-called Laval Quartet including a special section in Volume 10 (20072008) which included contributions by M Rönnmar, A Dashwood, T Novitz, S Sciarra and S Deakin. There have also been a number of contributions analysing the Posted Workers Directive which are cited throughout this article.

10 Proposal for a Directive of the European Parliament and of the Council amending Directive 96/71/EC of the European Parliament and the Council of 16 December 1996 concerning the posting of workers in the framework of the provision of services $\operatorname{COM}(2016) 128$ final.
} 


\section{THE PWD THROUGH THE LENS OF 'EUROPEANISATION'}

'Europeanisation' has been defined broadly in the political science and governance literature. One of the earliest conceptualisations of the term was given by Ladrech who considered europeanisation as 'an incremental process of re-orienting the direction and shape of politics to the extent that EC political and economic dynamics become part of the organisational logic of national politics and policy making. ${ }^{11}$ A number of authors ${ }^{12}$ have since elaborated upon Ladrech's definition thereby widening it to include the development of political networks at a European level as well as 'transnational influences that affect national systems' ${ }^{13}$ within the concept of europeanisation. Following on from these definitions, 'EC political and economic dynamics' can be integrated into a member state's organisational structure through either a 'top-down' or a 'bottom-up' approach. In Europeanization and National Politics, Ladrech develops his earlier definition of europeanisation. He explicitly situates his approach to europeanisation in 'the 'top-down' perspective in which domestic change is traced back to EU sources.' ${ }^{14}$ In doing so, he follows the recommendation of Börzel and Risse ${ }^{15}$ to 'use the term europeanisation as focusing on the dimensions, mechanisms, and outcomes by which European processes and institutions affect domestic-level processes and institutions. ${ }^{, 16}$

In the legal literature, the discourse has tended to distinguish between measures adopted at an EU level which aim at harmonisation and coordination. ${ }^{17}$ The latter can take place through hard or soft law mechanisms. ${ }^{18}$ The rationale for pursuing such a form of europeanisation (whether through (minimum) harmonisation or coordination) in the sphere of social policy/labour law has varied over time but Barnard and Deakin identify four main strands prevalent in the debates accompanying the adoption of legislation: (1) response to the effects of the common market; (2) industrial/social citizenship; (3) capabilities; and, (4)

11 R Ladrech, 'Europeanization of Domestic Politics and Institutions: The Case of France' (1994) 32 (1) Journal of Common Market Studies 69, p 69.

12 See TA Börzel and T Risse, 'When Europe hits home: Europeanization and Domestic Change' (2000)

European Integration Online Papers 4:15; JP Olsen, 'The Many Faces of Europeanization' (2002) 40 (5)

Journal of Common Market Studies 921; and, the contributions in K Featherstone and CM Radaelli (eds), The Politics of Europeanization (Oxford University Press, 2003).

13 B Kohler-Koch, 'Europäisierung: Plädoyer für eine Horizonterweiterung' in M Knodt and B Kohler-Koch (eds), Deutschland zwischen Europäisierung und Selbstbehauptung (Campus, 2000).

14 R Ladrech, Europeanization and National Politics (Palgrave, 2010), p 15.

15 TA Börzel and T Risse, 'Europeanization: The Domestic Impact of European Union Politics' in KE Jørgensen, MA Pollack and B Rosamond (eds) Handbook of European Union Politics (Sage, 2007).

16 See note 14 above, p 22, citing Börzel and Risse, 'Europeanization' in Jørgensen, Pollack and Rosamond, Handbook of European Union Politics, p 485.

17 See further S Weatherill 'The Constitutional Context of (Ever-Wider) Policy-Making' in E Jones, A Menon and S Weatherill, The Oxford Handbook of the European Union (Oxford University Press, 2012), p 573 and P Syrpis, 'Should the EU be attempting to harmonise national systems of labour law?' in M Andenas and C Baasch Andersen (eds), Theory and Practice of Harmonisation (Elgar, 2012).

18 For example, the Open Method of Coordination does not seek to eliminate differences between labour law systems but instead to coordinate Member State employment policies. See further K.A. Armstrong, Governing Social Inclusion - Europeanization Through Policy Coordination (Oxford University Press, 2010); C Sabel and J Zeitlin (eds), Experimentalist Governance in the European Union: Towards a New Architecture (Oxford University Press, 2010); and, M Dawson, New Governance and the Transformation of European Law: Coordinating EU Social Law and Policy (Cambridge University Press, 2011). For an excellent overview of the transformation of European Social Policy governance see J Goetschy, 'EU Social Policy Content and Governance: A Complex Relationship with EU Economic Integration Over Time' in MJ Rodrigues and E Xiarchogiannopoulou (eds), The Eurozone Crisis and the Transformation of EU Governance (Globalisation, Europe, 2014). 
market-making. ${ }^{19}$ Often, however, there has been a lack of clarity in articulating the purpose of individual measures and of European social policy as a whole. Early Directives in the social policy sphere such as Directive 75/117/EEC on equal pay or Directive 75/129/EEC on Collective Redundancies sought to harmonise certain aspects of national labour law systems (but did so in different ways). The Maastricht Treaty marked the turn towards the pursuit of a social policy by the European Commission including an active involvement of the social partners which sought to put 'the flesh onto the rather insubstantial bones of the citizenship provisions introduced by Maastricht'. ${ }^{20}$ Directives negotiated during this period sought to achieve levels of minimum harmonisation. ${ }^{21}$ Directive 2002/14 establishing a general framework for information and consultation marked the culmination of an eight year period of active legislating in the area of social policy by the Commission and the social partners. Even though Directives on social policy are still sporadically negotiated ${ }^{22}$, soft law mechanisms have, since 2002, taken over as the preferred method for achieving a coordination of labour standards across the EU.

The EU's approach to the europeanisation of social policy can be contrasted with the europeanisation of European private international law rules ${ }^{23}$ where the 'desire to achieve uniformity of decision in furtherance of continued integration of the EU acquis has overridden the willingness to continually accommodate national divergences. ${ }^{24}$ As Evju explains, the 'PWD is born out of a private international law background [...] [t]his is reflected in the comprehensive references to the Rome Convention and private international law [in the] Preamble.'25 The PWD thus straddles two areas - albeit based on neither legal base (see below) - by establishing a framework for determining which minimum labour rights in host countries are applicable to workers sent temporarily to work in another Member State. At the same time, the PWD does not shield host state workers from having to compete with cheaper foreign labour, if workers are posted from a low-wage country.

The PWD was first proposed in 1991 when the European Commission sought to regulate the provision of services in an attempt to find a balance between workers' rights and the free provision of services. ${ }^{26}$ This followed the decision by the CJEU in Rush Portuguesa ${ }^{27}$

\footnotetext{
19 C Barnard and S Deakin, 'Social Policy and Labour Market Regulation' in E Jones, A Menon and S Weatherill, The Oxford Handbook of the European Union (Oxford University Press, 2012) from p 546 onwards.

20 Ibid, p 547.

21 For example, the various Directives guaranteeing equality rights or individual labour rights including the Pregnant Workers Directive 92/85/EEC, [1992] OJ L 348 or the Fixed-Term Workers' Directive 99/70/EC, [1999] OJ L 175. Some of these Directives were negotiated by the social partners as framework directives (for example Directive 99/70/EC).

22 For up to date information see http://ec.europa.eu/employment_social/social dialogue/index en.htm.

23 For an overview see R Fentiman, 'Choice of Law in Europe: Uniformity and Integration' (2008) 82 Tulane Law Review 2021; C Twigg-Flesner, The Europeanisation of Contract Law (Routledge, 2008); A Dickinson, 'European Private International Law: Embracing New Horizons or Mourning the Past?' (2005) 1 (2) Journal of Private International Law 197.

24 L Gillies, 'Creation of Subsidiary Jurisdiction Rules in the Recast of Brussels I: Back to the Drawing Board?’ (2012) 8 (3) Journal of Private International Law 489, p 493.

25 S Evju, 'Cross-Border Services, Posting of Workers, and Jurisdictional Alternation' (2010) 1 (1) European Labour Law Journal 89, p 89.

26 J Cremers, JE Dølvik and G Bosch, 'Posting of workers in the single market: attempts to prevent social dumping and regime competition in the EU' (2007) 38 (6) Industrial Relations Journal 524, p 526. See also Commission Proposal for a Council Directive concerning the posting of workers in the framework of the provision of services COM(91) 230 final.
} 
where the Court held that Community law does not preclude host Member States from extending their legislation, or collective labour agreements entered into by both sides of industry, to any person who is employed, even temporarily, within their territory, no matter in which country the employer is established. The decision in Rush Portugesa concerned Portuguese workers working for a Portuguese entrepreneur in France. Due to the Accession Act, the Portuguese workers did not benefit from the free movement of workers at the time however the Court found that the employer, as a service provider, was entitled to make use of his rights under the Treaty "with all his staff ${ }^{28}$. France was given permission to extend its domestic labour laws to posted workers although posted workers were not given a right to equal treatment with employees of host State establishments as they were not considered to be moving as workers under the relevant Treaty provisions. ${ }^{29}$ In effect, the Court clarified that national treatment by the host State, as far as labour standards were concerned, did not amount to indirect discrimination against home State service providers. ${ }^{30}$ At the same time, the Court firmly placed the regulation of posted work within the scope of the freedom to provide services rather than the free movement of workers.

The Commission's subsequent proposal to regulate the cross-border temporary provision of services aimed to create legal certainty for the employer. ${ }^{31}$ The proposal met with opposition from Member States and the European Parliament, and an amended proposal was put forward in 1993 which, following a number of revisions, was adopted in $1996 .{ }^{32}$ The legal base for the Directive can be found in articles 56 and 62 TFEU on the provision of services, rather than in the social policy provisions. Thus, although the PWD was adopted in order to protect workers' rights, the primary aim of the Directive is to facilitate the crossborder provision of services. ${ }^{33}$

This ambiguity complicates the characterisation of the PWD. On the one hand, it identifies minimum standards of core working conditions in article 3(1) which should be guaranteed to posted workers so as to fulfil the PWD's objective of protecting the rights of workers. These include working time and annual holidays, minimum rates of pay, the regulation of temporary work, health and safety, measures which aim to protect pregnant women and young people, and equality of treatment between men and women. The concept of minimum rates of pay is defined by the national law and/or practice of the Member State to whose territory the worker is posted. Minimum rates of pay must be laid down by law, regulation or administrative provision, and/or by collective agreements which have been

27 Rush Portuguesa Lda v. Office national d'immigration, C-113/89, EU:C:1990:142. The decision in Rush Portugesa is widely regarded as instrumental in the adoption of the PWD. See, eg, J Dølvik and J Visser, 'Free movement, equal treatment and workers' rights: can the European Union solve its trilemma of fundamental principles?' (2009) 40 (6) Industrial Relations Journal 491. However, Evju traces a much longer and more complex background to the Directive in S Evju, 'Revisiting the Posted Workers Directive: Conflict of Laws and Laws in Contrast' (2009-2010) 12 Cambridge Yearbook of European Legal Studies 151.

28 Rush Portuguesa Lda v. Office national d'immigration, EU:C:1990:142, paragraph 12.

29 See M Houwerzijl, "'Regime shopping” across (blurring) boundaries' in S Evju (ed), Regulating Transnational Labour in Europe: The quandaries of multilevel governance (Skriftserie nr. 196, 2014).

30 P Davies, 'Posted Workers: Single Market or Protection of National Labour Law Systems?' (1997) 34 (3) Common Market Law Review 571.

31 COM(91) 230 final and see Evju, note 27 above.

32 See Evju, ibid p 166. Of particular concern were provisions on the way in which a host country's labour laws were to be laid down. Denmark and Italy also tabled amendments to make provision for the regulation of posted workers' rights by collective agreements of 'general applicability' and by those agreements concluded by the most representative organisations.

33 See note 30 above, pp 572-573. See also Evju, note 27 above, p 169. 
declared universally applicable. ${ }^{34}$ However, those moving as posted workers cannot claim a general right to equal treatment with national workers on the basis of EU law. The PWD does not, therefore, provide for any substantive labour law norms and seems to be a 'mere' coordinating instrument in the field of labour law. ${ }^{35}$ On the other hand, the PWD is not considered to be truly a conflict of laws instrument since neither its aims nor legal base follow the same approach taken by private international law instruments. The technique adopted by the PWD is also different to that of the Rome I Regulation. ${ }^{36}$ In light of this dichotomy, it is submitted that the PWD attempts to europeanise the applicability of national labour law systems - rather than the content of those systems themselves - in ways similar, but not identical, to conflicts of law instruments (in that Member States are required to deviate from the normal conflicts of law instruments for posted workers). ${ }^{37}$ The extent to which it is successful in this regard must, however, be questioned.

\section{IMPLEMENTATION PROBLEMS OF THE PWD}

The implementation of the PWD has proved problematic, due to the diverse interpretation of the provisions in national labour law systems. It has been argued that the Directive does not take sufficient account of differences in national industrial relations systems. ${ }^{38}$ Effective national implementation has often been lacking, particularly in the area of enforcement of the Directive's provisions. In a 2003 Communication on the implementation of the Directive ${ }^{39}$, the Commission concluded that the Directive had encountered difficulties in its practical implementation. A Resolution adopted by the European Parliament in 2004 considered the Directive to be insufficient to combat unfair competition (social dumping). Such findings were highlighted in the debate around the so-called 'Bolkestein Directive', first proposed in 2004, which sought inter alia to remove barriers to temporary service provision between Member States and which brought tensions between high-wage and low-wage Member States to the fore. ${ }^{40}$ The combination of weak monitoring, lack of effective enforcement, and allegations of social dumping were also exacerbated by the EU enlargements which occurred in 2004 and 2007 when the debate on the effectiveness of the Directive was given a new lease of life due to large numbers of workers being sent from new to old Member States. ${ }^{41}$ In

\footnotetext{
34 See further article 3(8).

35 This also follows from A van Hoek and M Houwerzijl's analysis in "'Posting" and "Posted Workers": The Need for Clear Definitions of Two Key Concepts of the Posting of Workers Directive' (2011-2012) Cambridge Yearbook of European Legal Studies 419, pp 437-443.

36 For a thorough overview of the differences between the PWD and Rome I see A van Hoek, 'Private international law rules for transnational employment: Reflections from the European Union' in A Blackett and A Trebilcock, Research Handbook on Transnational Labour Law (Edward Elgar, 2015); Evju, note 25 above; L Merrett, 'Posted Workers in Europe from a Private International Law Perspective' (2010-2011) Cambridge Yearbook of European Legal Studies 219; Van Hoek and Houwerzijl, note 35 above; and, Houwerzijl, note 29 above.

37 For a thorough analysis see Merrett ibid; van Hoek and Houwerzijl, note 35 above; and, Evju, note 27 above.

38 See note 26 above.

39 Report from the European Commission on the Implementation of Directive 97/71/EC concerning the Posting of Workers in the Framework of the Provision of Services COM(2003) 458.

40 For a detailed analysis of the proposal and the objections thereto from a labour law perspective see $\mathrm{C}$ Barnard, 'The Services Directive 2006/123 and Employment Law' in M Rönnmar (ed), EU Industrial Relations vs National Industrial Relations (Kluwer, 2008).

41 For an analysis of the impact of the enlargements on 'old' Member States' labour law systems see R Zahn,
} 
practice, this has led to waves of protest across old Member States against cheap labour originating from new Member States. ${ }^{42}$

Workers from new Member States often fail to receive the rights due to them under the PWD. The results of a Commission survey amongst Member States, the social partners and the European Parliament published in 2007 found ineffective control mechanisms to ensure compliance with the Directive. ${ }^{43}$ This gave rise to criticism from the ETUC in its position on the Directive. According to the ETUC, coordination and cooperation among Member States is, in practice, almost non-existent ${ }^{44}$ which makes compliance with the Directive difficult. In practice, workers often suffer from a lack of information and, as a result, cannot avail themselves of the protection under the Directive. Although textual implementation of the Directive is not seen as the most obvious problem, its practical application is, and the PWD falls short of its objective of protecting workers' rights while ensuring a system of fair competition. ${ }^{45}$

Part of this difficulty stems from the method used by the PWD to europeanise the applicability of national labour law systems. In the spirit of conflict-of-laws rules, the PWD aims to create legal certainty for parties which, in turn, should facilitate the transnational provision of services. However, the PWD does not create rights for workers as such but instead requires host states to extend certain protections to posted workers if, and only if, those protections are in place within the host state. ${ }^{46}$ Unlike many of the worker protection measures, therefore, in 'traditional' labour law and social policy directives, the PWD neither gives posted workers specific rights nor does it establish equal treatment with host state workers.

The problems associated with the PWD came to the fore particularly strongly following the European enlargements in 2004 and 2007 which led to an increased number of posted workers being sent from 'new' to 'old' Member States. The CJEU was finally asked to give a ruling on the Directive in the Laval case ${ }^{47}$. The main focus of the CJEU's judgment was whether the collective action in the form of a blockade taken by trade unions in this case

New Labour Laws in Old Member States (Cambridge University Press, 2017).

42 For examples see T Krings, 'A Race to the Bottom? Trade Unions, EU Enlargement and the Free Movement of Labour' (2009) 15 (1) European Journal of Industrial Relations 49.

43 European Commission, Communication on the Posting of Workers in the framework of the provision of services $\operatorname{COM}(2007) 304$.

44 ETUC, ETUC position on the implementation of Directive 96/71/EC concerning the posting of workers in the framework of the provision of services, 14-15 March 2006, available at http://www.etuc.org/a/2222.

45 Although the text is at many points unclear. See M Houwerzijl and A van Hoek, Comparative study on the legal aspects of the posting of workers in the framework of the provision of services in the European Union, (Radboud University, 2011). Critics writing at the time of the adoption of the Directive questioned how the Court would interpret its provisions. See note 30 above. The CJEU was not asked to rule on many of the key aspects of the Directive prior to 2007. Most cases were decided before the deadline for the implementation of the Directive had passed.

46 The extent to which Member States have discretion in including certain provisions within the 'public policy' exception of the Directive (article 3(10)) was limited by the CJEU in Commission v Luxembourg, C319/06, EU:C:2008:350.

47 There is a vast amount of literature on the case and its aftermath. For a small selection of literature see the website of the European Trade Union Institute (http://www.etui.org/Topics/Social-dialogue-collectivebargaining/Social-legislation/The-interpretation-by-the-European-Court-of-Justice/Reaction-to-thejudgements/Articles-in-academic-literature-on-the-judgements). Laval forms part of a 'Quartet' of cases decided at a similar time which included The International Transport Workers' Federation and The Finnish Seamen's Union v Viking Line, C-438/05, EU:C:2007:772; Rüffert v Land Niedersachsen, C-346/06, EU:C:2008:189; and, Commission v Luxemburg, EU:C:2008:350. 
was compatible with the EU rules on the freedom to provide services (article 56 TFEU). Moreover, the capacity for minimum wages (and other work related benefits) to be set for posted workers by collective bargaining by trade unions in the host State was cast into doubt. The relevant collective agreement in this case provided for more favourable conditions than those envisaged by the PWD. The Court, therefore, considered whether the collective action taken was justifiable in light of its objective, namely, to force a service provider to grant more favourable conditions to its workers than those prescribed by EU law.

In response the Court, first, reiterated its settled case law on the free movement of services which allows a Member State to apply its legislation or collective agreements to a service provider as long as the application of these rules is appropriate for securing the protection of workers and does not go beyond what is necessary for the attainment of the objective. ${ }^{48}$ Against this background, the PWD therefore lays down a level of minimum protection the exact content of which may be defined by the individual Member States. ${ }^{49}$ However, the Court did not accept the method of implementation of the PWD in Sweden where the applicable rates of pay were negotiated on a case by case basis through the social partners without being supplemented by legislation providing for universal applicability: it concluded that this leads to a climate of unfair competition as between national and posted service providers. ${ }^{50}$ Furthermore, the Court pointed out that the PWD does not allow the host Member State to make the provision of services in its territory conditional on the observance of terms and conditions of employment which go beyond the mandatory rules for minimum protection, as laid down in Art. 3(1) of the Directive.

The judgment has been heavily criticised for its potential to limit trade unions' rights to take collective action and for its failure to take into account the successful and flexible system of collective bargaining prevalent in Sweden. ${ }^{52}$ It also 'effectively settled" ${ }^{53}$ any doubts over the hierarchy of the PWD's objectives with the economic arguments clearly taking precedence over concerns for the protection of workers' rights. If we view the PWD as an attempt to europeanise the applicability of national labour law systems, it is arguable that the difficulties brought to the fore in Laval stem not from the actions of the social partners but from an unsuccessful adaptation to this europeanisation of the Swedish industrial relations system. In addition, the PWD's legal base meant that the CJEU could interpret the measure as one that should primarily facilitate the transnational provision of services. Thus, following the Laval Quartet, it became clear that the PWD fails to europeanise the applicability of national labour law systems adequately with a view to fulfilling its objectives on two accounts: first, the practical application of the Directive remains a problem; and, second, the PWD's provisions are not sufficiently clear in terms of the scope of rights which

\footnotetext{
48 Laval un Partneri Ltd, EU:C:2007:809, paragraph 56.

49 Ibid, paragraphs 58-60.

50 Ibid, paragraphs 71 and 80-81.

51 Ibid, paragraph 80 .
}

52 There is a substantial amount of literature discussing the judgments, not all of which can be mentioned in this section. For different views on the judgments see, for example, M Freedland and J Prassl, Viking, Laval and Beyond (Hart, 2004); M Rönmar (ed), EU Industrial Relations vs National Industrial Relations. Comparative and Interdisciplinary Perspectives (Kluwer, 2008); R Blanpain and AM Swiatkowski (eds), The Laval and Viking Cases: freedom of services and establishment $v$ industrial conflict in the European Economic Area and Russia (Kluwer, 2009); and articles by A Dashwood, T Novitz, M Rönnmar, S Deakin and S Sciarra in C Barnard (ed), Cambridge Yearbook of European Legal Studies, (2007-2008) Vol. 10.

53 See note 27 above, p 169. 
Member States can grant to posted workers. ${ }^{54}$ As a consequence, the CJEU's interpretation of the PWD's provisions means that the PWD is not able to accommodate the Swedish industrial relations system without it undergoing major reform.

Following the Laval Quartet, the European social partners were invited by the European Commission to respond to the consequences of the CJEU's case law. A joint report was issued in 2010. ${ }^{55}$ In addition, the ETUC argued for a revision of the PWD and for a Social Progress Protocol ${ }^{56}$ to be attached to the EU Treaties. ${ }^{57}$ Already in 2008, the European Parliament had called for changes to be made to the PWD in order to improve its correct application and enforcement. In 2010, the European Economic and Social Committee argued in favour of the PWD's revision in order to improve its implementation. In 2012, the Commission issued proposals for an Enforcement Directive ${ }^{58}$ and a Regulation ${ }^{59}$ (the 'Monti II Regulation') to regulate the right of workers to take collective action. Although the Monti II Regulation failed to see the light of day ${ }^{60}$, the Enforcement Directive was adopted with minor amendments in May 2014. ${ }^{61}$ As its name suggests, the Enforcement Directive aims inter alia to raise awareness of workers and companies about their rights and obligations as regards the terms and conditions of employment; improve cooperation between national authorities in charge of posting; clarify the definition of posting increasing legal certainty for posted workers and service providers ${ }^{62}$; and define Member States' responsibilities to verify compliance with the rules laid down in the PWD. The Enforcement Directive also introduces liability for subcontractors in the construction industry. Although the Enforcement Directive attempts to address some of the issues surrounding effective enforcement of the PWD, it does not alleviate many of the concerns raised by the CJEU's judgments in Laval. The ETUC confirms this view in its reaction to the Directive: 'Measures to be taken by member states to combat abuse and under-payment of posted workers should not be subject to free market

\footnotetext{
54 This comment refers to the definition of 'minimum rates of pay' discussed below but also more generally in relation to the interpretation of article 3(10) PWD which is discussed in more detail in Merrett, note 26 above.

55 ETUC, Report on joint work of the European social partners on the ECJ rulings in the Viking, Laval, Rüffert and Luxembourg cases, 19 March 2010, available at http://www.etuc.org/sites/www.etuc.org/files/Joint_report_ECJ_rulings_FINAL_logos_19.03.10_1.pdf.

56 The idea of a Social Progress Protocol is not new. For an overview of the discussion see A Bücker, 'A comprehensive Social Progress Protocol is needed more than ever' (2013) 4 (1) European Labour Law Journal 4.

57 ETUC, The Posting of Workers Directive: proposals for revision, 9-10 March 2010, available at http://www.etuc.org/documents/posting-workers-directive-proposals-revision\#.VBwN8hb9mMk.

58 European Commission, Proposal for a Directive of the European Parliament and of the Council on the enforcement of Directive 97/71/EC concerning the posting of workers in the framework of the provision of services, $\mathrm{COM}(2012) 131$ final.

59 European Commission, Proposal for a Council Regulation on the exercise of the right to take collective action within the context of the freedom of establishment and the freedom to provide services, $\mathrm{COM}(2012)$ 130 final.

60 For an overview of the difficulties encountered by the Regulation see The Adoptive Parents, 'The Life of a Death Foretold: The Proposal for a Monti II Regulation' in M Freedland and J Prassl, Viking, Laval and Beyond (Hart, 2015) and F Fabbrini and K Granat, "'Yellow Card but no Foul": the Role of the National Parliaments under the Subsidiarity Protocol and the Commission Proposal for an EU Regulation on the Right to Strike' (2013) 50 (1) Common Market Law Review 115.

61 Directive 2014/67/EU [2014] OJ L 159. Member States had until 18 June 2016 to transpose the Directive. For an analysis of the Directive see J Cremers, 'Economic freedoms and labour standards in the European Union' (2016) 22 (2) Transfer 149.

62 For a discussion of the need for clarify on the definition of posting see note 35 above.
} 
rules. The current text does not guarantee that. Rules applying to posted workers falling outside the scope of the directive are not clear either. ${ }^{63}$ In particular, the Enforcement Directive does not address inequality of treatment between posted and local workers, and it fails to introduce an EU-wide monitoring system which could help to reduce problems of differential treatment across Member States. In addition, the Enforcement Directive does little to tackle problems related to the definition of pay which has raised particular concerns. ${ }^{64}$

In its subsequent case law on the PWD, the CJEU has sought inter alia to clarify the notion of 'minimum rates of pay'. ${ }^{65}$ The facts of the case in Sähköalojen ammattiliitto ry ${ }^{66}$ have much in common with the Laval case ${ }^{67}$ : Polish workers posted to work on a Finnish construction site were not paid the minimum remuneration due to them under the relevant Finnish collective agreement and assigned their pay claims to a Finnish trade union. However, unlike in Laval, the relevant collective agreement was generally applicable; it was therefore easier to implement the PWD in Finland than in Sweden. The collective agreement provided for a calculation of minimum pay which included inter alia holiday allowance, compensation for travelling time and accommodation costs, and a daily allowance. The dispute at issue therefore centred on the definition of 'minimum rates of pay' under article 3 of the $\mathrm{PWD}^{68}$; the Finnish industrial relations system as such was not subject to challenge. In its judgment, the CJEU clarified that a host Member State can require sending companies to include in the payment to posted workers holiday allowances, daily flat-rate allowances to compensate workers for disadvantages entailed by the posting, and compensation for travelling time, on equal terms as local workers; provided these constituent elements of the minimum wage do not have the effect of impeding the freedom to provide services. ${ }^{69}$ Moreover, the ruling acknowledged that if collective agreements set different pay levels related to the categorisation of employees into pay groups, these pay levels need to be considered as valid in line with the Directive, provided that the conditions are universally binding and transparent. ${ }^{70}$ However, the CJEU in this case permitted the exclusion of posted workers from specific allowances relating to the costs of accommodation and meal vouchers, which workers in the host state received. ${ }^{71}$ Although the judgment leaves it up to the national

63 ETUC, Provisional deal on posting of workers will not put an end to social dumping, 5 March 2014, available at http://www.etuc.org/press/provisional-deal-posting-workers-will-not-put-end-socialdumping\#.VBwW4xb9mMk.

64 See D Schiek, EU Social and Labour Rights and EU Internal Market Law: Study for the EMPL Committee (European Parliament, 2015), p 62 which found that problems relating to fair working conditions for posted workers were the most prevalent. Respondents from trade unions and labour inspectorates from the Member States analysed expressed concern that posted workers were paid significantly lower wages than other workers in the host States.

65 It has also been concerned with the use of public procurement legislation to enforce labour standards. See Bundesdruckerei v Stadt Dortmund, C-549/13, EU:C:2014:2235 and Regio Post v Stadt Landau, C-115/14, EU:C:2015:760.

66 Sähköalojen ammattiliitto ry v Elektrobudowa, C-396/13, EU:C:2015:86.

67 Opinion of Advocate General Wahl's Opinion in Sähköalojen ammattiliitto ry, EU:C:2015:86, paragraphs 33,34 and 67.

68 The CJEU was also asked to rule on the division of competences between the Finnish and Polish trade unions.

69 See also Tevfik Isbir v DB Services GmbH, C-522/12, EU:C:2013:711.

70 Sähköalojen ammattiliitto ry, EU:C:2015:86, paragraphs 42 and 44.

71 The reasoning justifying such exclusions based itself on an interpretation of article 3(7) of the PWD. See Sähköalojen ammattiliitto ry, EU:C:2015:86, paragraphs 58-63. See also Opinion of Advocate General Wahl at paragraphs 110-114 where he distinguishes between allowances specific to the posting which are considered as part of the minimum wage and allowances paid in reimbursement of expenditure actually 
court to determine whether certain allowances form part of the minimum wage, the CJEU also reiterated the principle that posted workers are only entitled to minimum protection and not to equal treatment. ${ }^{72}$ The lack of a clear definition of 'minimum rates of pay' and the absence of an equal treatment principle in the PWD, particularly in relation to pay, have continued to attract widespread criticism of the Directive. This raises concerns over the extent to which the PWD, in its current form, can successfully europeanise the applicability of national labour law systems in order to fulfil its objective of promoting the transnational provision of services while also providing for a climate of fair competition (for host State workers) and protecting (posted) workers' rights.

The next section discusses the Directive's remaining gaps in protection. Moreover it identifies a number of unintended consequences of what $I$ see as an unsuccessful europeanisation triggered by the Directive in its current form, namely the extent to which it leads to discrimination on the grounds of skill levels and gender.

\section{REMAINING GAPS IN PROTECTION OF WORKERS’ RIGHTS}

\section{A. Remaining gaps in protection}

The PWD covers three different types of posting: 'normal' posting (article 1(3)(a)) whereby undertakings post workers to another Member State in order to provide services in that State; intra-corporate posting (article 1(3)(b)); and, posting through temporary agencies (article $1(3)(c))$. The first type of posting is the least problematic and often, but not always, involves highly-skilled, highly-paid workers. ${ }^{73}$ In relation to intra-corporate posting, the picture is more varied and there have been some reports of subsidiaries, particularly in labour-intensive sectors, being created in order to circumvent labour standards and other obligations. ${ }^{74}$ As Cremers argues, 'the cost advantages of posting from a low social security country to a country with 'normal' social security costs can mount up to $25-30 \%$. Other cost advantages are obtained if posted workers are not properly paid according to the correct skill/qualification level so that such workers are subject to minimum pay and conditions, instead of the equivalents paid to the ordinary workforce in the host State. ${ }^{75}$ In the latter case, the cost advantages can be much higher. Most issues arise however in the third scenario when temporary work agencies are involved; this is most prevalent in the construction sector where there have been reports of agencies established purely for the purpose of circumventing the application of labour standards. ${ }^{76}$ It is estimated that posting of workers

\footnotetext{
incurred on account of the posting, such as expenditure on travel, board and lodging. The latter cannot be classified as being part of the minimum wage. For a more differentiated analysis see M Houwerzijl and A van Hoek, 'Where do EU mobile workers belong, according to Rome I and the (E)PWD' in H Verschueren (ed), Residence, employment and social rights of mobile persons: on how EU law defines where they belong, (Intersentia, 2016).

72 Sähköalojen ammattiliitto ry, EU:C:2015:86, paragraph 30.

73 See further J Cremers, In search of cheap labour in Europe: Working and living conditions of posted workers (CLR Studies 6, 2011).

74 Ibid, p 26.

75 Ibid.

76 Ibid. Although so-called 'letterbox' companies occur in all three types of posting. For more information and case studies see K. McGauran, The impact of letter-box type practices on labour rights and public revenue (ETUC, 2016).
} 
through temporary agencies represents, on average, $5 \%$ of total postings in the EU, albeit with significant cross-country variations. ${ }^{77}$

In those sectors where issues with posting have been reported, posted workers generally earn substantially less than local workers, with reports of income of less than $50 \%$ than that usually paid in a given place for the same job. ${ }^{78}$ This results in segmentation of the labour market which the PWD's provisions do little to prevent. Instead, the PWD's provisions on pay create inequality between posted and local workers by allowing for a structural differentiation of wage rules. This structural differentiation arises directly as a result of the PWD's imprecision over minimum rates of pay. First, the PWD only guarantees that posted workers will be paid minimum rates of pay as part of a 'hard core of clearly defined protective rules, ${ }^{79}$ while in the host Member State. Minimum rates of pay are defined either by the law or by universally applicable collective agreements. In the absence of universally applicable collective agreements, Member States may decide to base themselves on collective agreements which are generally applicable to all similar undertakings in the geographical area and in the profession or industry concerned, or collective agreements which have been concluded by the most representative employers' and labour organisations at national level and which are applied throughout national territory. ${ }^{80}$ However, in the wake of the 2008 financial crisis, both universally applicable collective agreements and general/sectoral collective bargaining systems have been progressively dismantled across a number of Member States as a direct consequence of austerity policies. ${ }^{81}$ In the absence of collective agreements which comply with the requirements of the PWD, posted workers are only entitled to whatever statutory minimum wage that there might be in the receiving country. This, in effect, means that posted workers may be paid substantially less than local workers for the same work. In addition, even when collective agreements are applicable, it is widely reported that sending companies tend to pay the rates applicable to the lowest pay group, rather than the adequate pay group corresponding to workers' job tasks, educational level and seniority. ${ }^{82}$

Second, the composition of the minimum rates of pay guaranteed to posted workers in the host Member States is unclear. In Sähköalojen ammattiliitto ry, the CJEU only clarified selected issues of the concept of 'minimum rates of pay'. Article 153 TFEU expressly excludes pay from the EU's competence and the definition and composition of 'minimum rates of pay' therefore varies enormously across the Member States. For example, certain bonuses or allowances (such as Christmas bonus or seniority bonus) are constituent parts of pay in some Member States but not in others. The absence of a clear definition of the constituent elements of pay results in legal uncertainty and practical difficulties for: the

\footnotetext{
77 All figures are drawn from the Commission's Impact Assessment, see note 1 above. It should be noted that strong data limitations on posting of workers remain an on-going problem. There have been a number of studies which have sought to look in more detail at the problems surrounding the interaction between posting and temporary work and this is not discussed in more detail here. See further note 73 above and note 45 above.

78 See note 1 above, p 13.

79 Preamble to the Directive, paragraph 14.

80 Article 3(8) PWD.

81 The effect of the crisis on national labour law systems is explained by the ETUI in individual country reports here: https://www.etui.org/Publications2/Working-Papers/The-crisis-and-national-labour-law-reformsa-mapping-exercise. See also A Koukiadaki, I Tavora, and M Martinez-Lucio, Joint Regulation and Labour Market Policy in Europe during the Crisis (ETUI, 2016).

82 See note 1 above.
} 
bodies responsible for the enforcement of the rules in the host Member State; for the service provider when determining the wage due to a posted worker; and for the awareness of posted workers themselves about their entitlements. For the latter, access to knowledge about entitlements to pay is rendered even more difficult by the fact that the language, laws and legal system of a host State are likely to be foreign to posted workers who can also be left without effective local trade union representation.

Finally, there are uncertainties concerning the implementation of the PWD in Denmark and Sweden who lack both a statutory minimum wage and a scheme for the extension of collective agreements in accordance with the Directive. In Sweden, the judgment in Laval continues to negatively impact trade unions. As Woolfson et al. point out, '[b]y circumscribing the right of national trade unions to undertake collective action to enforce domestic terms and conditions on foreign employers sending workers to Sweden, the ECJ in Laval highlighted the soft underbelly of the Swedish model of autonomous collective bargaining pay formation. ${ }^{, 83}$ As a result, the number of collective agreements concluded with foreign employers has dropped significantly. ${ }^{84}$ In the area of construction, the Swedish trade union confederation, LO, produced a report in 2010 which examined the use of posted workers for three large infrastructure projects in Malmö and Stockholm. ${ }^{85}$ The report found that large numbers of foreign workers (mainly Polish) were posted to work on the building sites by Polish or Irish employment agencies at wages below the relevant collective agreements. In its response, LO called for increased regulation of posted work in Sweden in order to ensure that collective agreements are observed ${ }^{86}$ A Lex Laval which was passed in 2010 permits trade unions to take collective action with the aim of regulating the employment conditions of posted workers if certain criteria are met: first, the conditions at issue must correspond to generally applicable conditions in the relevant sector; second, trade union demands may only concern minimum pay or other conditions contained in the Directive; and, third, collective action is not permitted with a view to achieving 'a Swedish collective agreement if an employer can show that the employees are already included in terms and conditions (regardless if stipulated by collective agreement, employment contract or managerial decision) that are at least as good as those in a Swedish central branch agreement. ${ }^{87}$ Swedish trade unions complained about the Lex Laval to the ILO and the European Committee of Social Rights who both upheld the complaints. ${ }^{88}$ There is a widespread recognition that the legislation has severe shortcomings yet both employer associations and trade unions recognise that 'it is difficult to find a model that is compliant

\footnotetext{
$83 \mathrm{C}$ Woolfson, J Fudge and C Thörnqvist, 'Migrant precarity and future challenges to labour standards in Sweden' (2014) 35 (4) Economic and Industrial Democracy 695, p 699.

84 Ibid, p 709.

85 C-M Jonsson, T Pettersson, H Löfgren and K Arvidsson, När arbetskraftskostnaderna presser priset - en genomlysning av offentliga investeringar $i$ infrastruktur (LO-rapporten, 2010). See also C Thörnqvist and S Bernhardsson, 'Their own stories? How Polish construction workers posted to Sweden experience their job situation, or resistance versus life projects' (2015) 21 (1) Transfer 11.

86 Ibid, 34-7.

87 Prop 2009/10:48.

88 See Complaint No. 85/2012 Swedish Trade Union Confederation (LO) and Swedish Confederation of Professional Employees (TCO) v Sweden, 12 July 2012 and ECSR, Decision on Admissibility and the Merits Complaint No. 85/2012 Swedish Trade Union Confederation (LO) and Swedish Confederation of Professional Employees (TCO) v Sweden, 3 July 2013. For a discussion of the ECSR's decision see C Barnard, 'More Posting' (2014) 43 (2) Industrial Law Journal 194.
} 
with the Swedish industrial relations model and the Court's case law. ${ }^{89}$ Following political pressure, a further parliamentary governmental inquiry on posting of workers was set up in September 2012 with the aim of evaluating the Lex Laval.

In practical terms, the PWD's differentiated rules on wages clearly translate into a competitive advantage for posting companies over local companies in host countries. According to Eurostat data for 2014, an average hour of work costs an employer $€ 40$ in Denmark and $€ 39$ in Belgium, but only $€ 3.80$ in Bulgaria, $€ 4.60$ in Romania and $€ 8.40$ in Poland. $^{91}$ Competitive advantages in relation to wages particularly affect domesticallyprovided services, such as construction and personal services; given their labour-intensive and price-sensitive character and the fact that delocalisation of these activities is not possible. $^{92}$ However, there are also wide variations between sectors and countries. Posted workers are reported to receive a lower remuneration level than local workers, especially in high-wage EU receiving countries, such as Belgium, Denmark, France, Germany, the Netherlands and Sweden. Because of the absence of data on the earnings of posted workers, only gross estimates exist. However, the wage gap is estimated to range from $10-15 \%$ in the Danish construction sector, up to about $25 \%-35 \%$ in the construction sector in the Netherlands and Belgium, and up to $50 \%$ in the road transport sector in Belgium. ${ }^{93}$ In addition, the Commission suggests ${ }^{94}$ that wage differentiation is reported to be especially acute in two cases. First, posted workers in labour-intensive, low-skilled sectors, such as the construction sector and road transport are more likely to receive minimum pay rates than posted workers in high-end service sectors, e.g. finance and insurance. This is because in these sectors labour cost differentials are one of the key drivers of posting of workers. By contrast, the Commission's Impact Assessment 95 suggests that in sectors or for professions in which posting is driven by skills shortages, such as the care services sector, or when workers have higher skills, wages are not reported to be a problematic issue. Second, unequal wage treatment particularly affects workers posted from low- to high-wage countries. Although the PWD does not preclude companies from applying more generous conditions than the minimum standards of the host country, it does not exert any pressure on companies to do so and workers posted from low-wage countries tend to lack the bargaining power to obtain more generous conditions in line with the wage standards of the receiving countries. Within the host Member State itself, the PWD therefore has the potential to create a downward spiral of wage and labour cost competition which may have a negative impact on

\footnotetext{
89 See note 64 above, p 66.

90 See Kommittédirektiv Dir 2012:92. This Committee reported its findings on 26 October 2015. See Översyn av lex Laval, SOU 2015:83, available at http://www.regeringen.se/contentassets/d90af7051ee54a499950155582431922/oversyn-av-lex-laval-sou201583. The Committee made a number of suggestions for reform which at the time of writing were passing through the Swedish Parliamentary process.

$91 \mathrm{http} / /$ ec.europa.eu/eurostat/statistics-explained/index.php/Hourly labour_costs.

92 See note 1 above, p 13.

93 The figures in this paragraph all stem from the Commission's Impact Assessment, see note 1 above. See also Fondazione Giacomo Brodolini (FGB), Study on wage setting systems and minimum rates of pay applicable to posted workers in accordance with Directive 96/71/EC in a selected number of Member States and sectors, Final report, November 2015 and note 64 above.

94 See note 1 above, pp 13-14.

95 Ibid, p 14
} 
local workers and risks destabilising coordinated wage-setting regimes and the bargaining autonomy of the social partners in those countries. ${ }^{96}$

The rise in posted work points to the PWD's success in fulfilling its first objective: the promotion of the transnational provision of services. However, the lack of clarity over 'minimum rates of pay' and the absence of an equal treatment principle create conditions which in certain sectors clearly fall short of and, indeed mean that the PWD is merely paying lip service to its second and third objectives: the creation of a climate of fair competition and the guarantee of respect for the rights of workers. In addition, the PWD has the unintended consequence of further entrenching existing inequalities in relation to skill levels and gender.

\section{B. Skill levels}

The PWD is sufficiently broad to cover a whole host of different types of posting (high skilled and low skilled). However the fact that it does not establish a strong catalogue of rights for posted workers, and does not differentiate between different skill levels or sectors means that posted workers largely have to rely on their own bargaining power in order to achieve the same conditions as local workers. The PWD as such only provides a minimum floor of guaranteed rights. This has the effect of entrenching existing inequalities on the grounds of skill levels.

The phenomenon of posted work has risen exponentially since the recent EU enlargements and while the general view is that increased free movement (whether of workers or under the umbrella of services) has been positive, there is also evidence that there has been some downward pressure on wages at the bottom end of the scale, particularly in low-skilled sectors. ${ }^{97}$ Although official statistics do not contain information about skill levels, the main sectors which have been particularly affected by this increase in posted workers construction and manufacturing - are those which have a high proportion of low-skilled labour. The European Builders Confederation (EBC) estimates that, between 2011 and 2014, close to 15,000 (over $8 \%$ of) workers in the construction sector in Belgium lost their job 'due to unfair competition showed by a constant increase of posted workers.' According to the $\mathrm{EBC}$, figures from the French construction sector are similar. ${ }^{98}$ It is the very nature of lowskilled work that workers are easy to replace and lack sufficient bargaining power in order to achieve equal treatment with local workers. In addition, lack of knowledge of language, local laws, customs and wage-setting practices in low-skilled sectors means that these posted workers are particularly vulnerable to inequality of treatment. It is in these sectors that there is the greatest disparity in wages between local and posted workers. The same is not true for highly-skilled posted workers where there is virtually no evidence of the posted workers being treated less well than local workers (on the contrary, they are either treated equally or better than local colleagues). ${ }^{99}$ The PWD therefore contributes to the phenomenon of

\footnotetext{
96 See N Lillie and I Wagner, Subcontracting, insecurity and posted work: evidence from construction, meat processing and ship building (ETUI, 2015).

97 For evidence of this in the UK see M Sumption and W Somerville, The UK's New Europeans: Progress and Challenges Five Years After Accession, Equality and Human Rights Commission Policy Report, together with the Migration Policy Institute, January 2010.

98 See note 3 above, p 7.

99 See note 1 above, p 14.
} 
widening income inequality across the $\mathrm{EU}^{100}$ and its potential to allow unequal treatment on the grounds of pay also entrenches inequality on the basis of skill levels.

\section{Gender}

There is a lack of reliable data on the gender composition of posted workers however one can make a number of general comments about gender-related aspects of the Directive. The Directive does not mention gender and appears gender neutral. It therefore seeks to provide for 'formal' equality between men and women. ${ }^{101}$ However, the very nature of posted work means that it is inherently disadvantageous to women especially as it is still the case that in most societies women have maintained primary care responsibilities. ${ }^{102}$ As such, in appearing gender neutral, the PWD does little to encourage 'substantive' equality. ${ }^{103}$ At the same time, it must be questioned whether the fact that the PWD does not encourage the posting of women workers is necessarily negative as the nature of much posted work - in low-wage sectors with often exploitative working conditions - represents far from a positive choice for women.

A large part of posted work occurs in the construction sector: a male-dominated industry with very high labour costs, since it is a labour-intensive sector. ${ }^{104}$ Posting here is particularly profitable as it allows employers to dramatically reduce labour costs. It is therefore not surprising that the majority of postings occur in this sector. The Commission however suggests that widespread unfair treatment on grounds of wages is not an issue in areas where posting is driven mainly by skills shortages rather than competition on the basis of pay. Domestically-provided personal services such as in the health and social care sector (referred to as 'care services') which are largely female-dominated stand out here. ${ }^{105}$ Such care work by its very nature tends to be low-paid ${ }^{106}$ so there is limited scope for competition on grounds

\footnotetext{
100 Ibid, p 13.

101 See Article 3(1)(g) PWD. It is beyond the scope of this paper to examine the differing theories which justify discrimination legislation. An overview of this can be found in S Fredman, Discrimination Law, (Oxford University Press, 2002), chapter 1 and N Bamforth, 'Conceptions of Anti-Discrimination Law' (2004) 24 (4) Oxford Journal of Legal Studies 693.

102 See OECD, Closing the Gender Gap: Act Now (OECD Publishing, 2012), pp 199 ff and W Patton, Conceptualising Women's Working Lives: Moving the Boundaries of Discourse (Sense Publishers, 2013), pp. 5-6.

103 See further L Jacobs, Pursuing Equal Opportunities (Cambridge University Press, 2004), chapter 5 and Fredman, note 101 above, chapters 1 and 4.

104 For an overview of the average costs see: http://ec.europa.eu/eurostat/statisticsexplained/index.php/Hourly_labour_costs.

105 See note 1 above, pp 13-14.

106 The feminisation of care is not restricted to the family sphere, but has also been reflected in paid care work. As the sector has grown, women have formed an ever larger majority of paid care workers. See further M Daly and K Rake, Gender and the Welfare State: care, work and welfare in Europe and in the USA, (Polity Press, 2003). In keeping with the low value assigned to caregiving in the private sphere, this sector is characterised by low pay and poor working conditions, devaluing the value of care in economic and employment terms. As the Migration Observatory points out, in the UK, social care, which includes a range of care-related occupations, e.g. care assistants in residential care homes and in home care services, is one of the lowest paid sectors of the labour market. The sector has historically been reliant on women, who have combined low paid part-time work in social care with unpaid caring responsibilities for families. Although the introduction of the National Minimum Wage in 1999 brought about an increase in average pay levels for social care workers, particularly in care homes, most pay has since stayed on or near the National Minimum
} 
of pay and therefore there is admittedly little unequal treatment here (in terms of pay) between posted and local workers. ${ }^{107}$ However, this then raises broader questions over the value of care work vis-à-vis comparable low-skilled work in male-dominated sectors such as construction. ${ }^{108}$

\section{THE NEWEST PROPOSAL - A REBALANCING OF OBJECTIVES?}

On 8 March 2016, the European Commission issued a set of proposals as part of its mobility package which included a proposal for a Directive amending the PWD. The proposed Directive is to complement the Enforcement Directive rather than to replace it. The proposed Directive replicates the PWD's objectives and aims to facilitate the provision of services across borders within a climate of fair competition while ensuring respect for the rights of posted workers. ${ }^{109}$ It has the same legal base as the PWD - firmly locating the regulation of posted work within the free movement of services - and focuses on three main areas: rules on temporary work agencies ${ }^{110}$; rules applying to long-term posting ${ }^{111}$; and, the remuneration of posted workers where it introduces the principle of equal pay for equal work.

In terms of pay, the Commission proposal replaces the reference to 'minimum rates of pay' in article 3(1) of the PWD with the term 'remuneration' and imposes an obligation on Member States to publish information on the constituent elements of remuneration. This would mean that employers would have to apply the rules of the host country in relation to pay/remuneration, as laid down by law or by universally applicable collective agreements, and not just the minimum rates of pay. In addition, rules set by universally applicable collective agreements will become mandatory in all sectors, whereas previously they were only mandatory in the construction sector. This amendment builds on the case law of the CJEU in Sähköalojen ammattiliitto ry by entitling posted workers to some of the same advantages such as bonuses, or pay increases according to seniority as local workers. The new proposal also extends the equal treatment principle to posted temporary agency workers vis-à-vis local temporary agency workers with respect to remuneration and working conditions.

\footnotetext{
Wage. See further http://www.migrationobservatory.ox.ac.uk/policy-primers/social-care-older-people-anddemand-migrant-workers.

107 For references see http://www.migrationobservatory.ox.ac.uk/policy-primers/social-care-older-peopleand-demand-migrant-workers. There have however been incidences of unequal treatment in relation to terms and conditions of work (not pay). For examples see Ver.di, Migrantinnen in Privathaushalten (ver.di, 2014) and F Colombo, A Llena-Nozal, J Mercier and F Tjadens, Help Wanted? Providing and Paying for LongTerm Care, (OECD Health and Policy Studies, 2011).

108 The concept of equal pay for work of equal value is enshrined in EU law. See the Recast Equal Treatment Directive 2006/54/EC [2006] OJ L 204/23 which consolidated inter alia previous directives on equal treatment and equal pay, and incorporated principles derived from CJEU case law. See also Enderby v Frenchay Health Authority, C-127/92, EU:C:1993:859 and Susanna Brunnhofer v Bank der österreichischen Postsparkasse $A G, \mathrm{C}-381 / 99, \mathrm{EU}: \mathrm{C}: 2001: 358$.

$109 \mathrm{http} / /$ ec.europa.eu/social/main.jsp?langId=en\&catId=471\&newsId=2488\&furtherNews=yes.

110 The proposal introduces the principle of equal treatment between posted and local temporary agency workers.

111 The proposal aligns the definition of a posting period ( 24 months) with that of the relevant social security provisions. The current PWD does not define when a posting ceases to be 'temporary'. Under the Commission's proposal, long-term posted workers will be covered by the mandatory rules of the host country's labour law system following a period of 24 months of posting.
} 
The Commission's proposal has already caused controversy. The ETUC considers the proposal a significant improvement but argues that it will result in a right 'to equal pay that many posted workers will never get. ${ }^{\prime 12}$ The proposal is certainly a step in the right direction in that it recognises a problem with the current definition of 'minimum rates of pay' and the way in which these are determined. The use of the term 'remuneration' allows for the inclusion of a variety of different elements as part of a pay package and gives social partners some discretion in bargaining over pay and its constituent parts. As Novitz points out, 'this would enable the PWD to reflect the more dynamic wage-setting realities in the contemporary labour market. ${ }^{113}$ The proposal also makes provision for mandatory standards to be set for posted workers in all sectors by collective agreements which have been declared universally applicable (currently this only applies to the construction sector). However, in practice this is likely to have limited effect. ${ }^{114}$ In addition, the proposed Directive continues to require wage setting through universally applicable collective agreements or legislation. There is only very limited recognition of the role played by sectoral or company-level agreements. $^{115}$ As such, the proposed Directive does little to tackle inequality in those countries, such as Germany or Italy which have no, or make limited use of, universally applicable or generally applicable collective agreements but rely instead on other forms of agreements. Posted workers working in sectors with universally binding collective agreements will therefore receive a higher level of protection than posted workers active in less regulated sectors. This not only creates inequality of treatment between different groups of posted workers but also raises a gender-dimension in that sectors such as the construction sector which are traditional trade union strongholds have been more successful than others ${ }^{116}$, such as the care sector, in developing transnational regulation of working conditions. Such issues could be better dealt with if there was better collection of data on posted workers, their characteristics and skill levels. However, although the European Commission recognised the unreliability of existing data on posted work ${ }^{117}$, the proposed Directive fails to establish a more reliable system for the collection of data. The proposed Directive has also been criticised for neither acknowledging a right for trade unions to bargain on behalf of posted workers nor does it address concerns over joint liability of sub-contractors and main contractors for respect of terms and conditions of employment. ${ }^{118}$ Finally, the proposed Directive does not address the two central concerns raised in the wake of the Laval case: first, that the PWD sets out a ceiling of protection (rather than a floor of rights) ${ }^{119}$; and, second,

\footnotetext{
112 https://www.etuc.org/press/posted-workers-revision-\%E2\%80\%93-equal-pay-some\#.V3PVEaIYF2A.

113 T Novitz, 'The Scope for Collective Bargaining in Posting and Procurement-What Might Come From Recent Court of Justice Case Law and the Proposed Reform of the Posting of Workers Directive?' April 6 2016 available at http://legalresearch.blogs.bris.ac.uk/2016/04/the-scope-for-collective-bargaining-in-postingand-procurement/.

114 The Commission anticipates that it will only have an effect in a limited number of Member States including Ireland and Luxembourg. See note 1 above, p 24.

115 See Article 1(2)(b) $\operatorname{COM(2016)~} 128$ final which deals with the situations of subcontracting chains and gives Member States the ability to oblige undertakings to subcontract only to undertakings that grant workers certain conditions on remuneration applicable to the contractor, including those resulting from non-universally applicable agreements. However, this is only possible on a proportionate and non-discriminatory basis and requires that the same obligations are imposed on all national sub-contractors.

116 See note 3 above, p 10.

117 See note 1 above.

118 https://www.etuc.org/press/posted-workers-revision-\%E2\%80\%93-equal-pay-some\#.V3PVEaIYF2A.

119 Although these concerns are partly addressed in Art. 1(2) COM(2006) 128 final in relation to pay and temporary agency workers.
} 
that collective action taken by trade unions to enforce posted workers' rights to better treatment must be proportionate.

Overall, therefore the revised proposal does not resolve the ambiguity which has underpinned the PWD - in its attempt to europeanise the applicability of national labour law systems - since its inception. Although the proposal is an improvement on the current Directive, it is still clearly a measure primarily aimed at facilitating the transnational provision of services rather than a worker protection measure; the continued absence of an equal treatment principle exemplifies this point. Particularly the provisions on the scope and regulation of pay do not take account of national divergences in wage setting mechanisms and fail to facilitate systems of labour law which do not have an extension mechanism for collective agreements. The extent to which the proposed Directive will therefore be more successful at europeanising the applicability of national labour law systems than the current PWD is therefore open to question.

The response to the proposed Directive by national parliaments shows diverging interests between Member States. ${ }^{120}$ Whereas the French parliament criticised the proposal for not providing sufficient protection for equality of treatment of posted workers, parliaments from Central and Eastern European Member States objected to the proposal on the grounds that a right to equal pay would harm competitiveness. As of 10 May 2016, fourteen chambers from eleven Member States (ten from Central and Eastern Europe, and Denmark) had made use of the Subsidiarity Control Mechanism to raise subsidiarity concerns and thereby triggered a "yellow card" 121 . In addition, six national parliaments (Spain, Italy (both the Camera dei Deputati and the Senate), Portugal, the UK and France) sent opinions considering the proposal as compatible with the principle of subsidiarity. Central and Eastern European countries had already opposed a review of the PWD prior to the publication of the current proposal on the basis that the principle of equal pay for equal work in the same place may be incompatible with the single market, as pay rate differences constitute one legitimate element of competitive advantage for service providers. In responding to the subsidiarity control mechanism, the Socialists and Democrats Group in the European Parliament issued support for the proposed Directive and rejected national parliaments' concerns. ${ }^{122}$ On 20 July 2016, the European Commission published a Communication ${ }^{123}$ which concluded that the proposed revision of the PWD did not breach the subsidiarity principle. The Commissioner for Employment, Social Affairs, Skills and Labour Mobility, Marianne Thyssen also reiterated that '[p]osting of workers is a cross-border issue by nature. The Juncker Commission remains firmly committed to the free movement of people on the basis of rules that are clear, fair for everybody and enforced on the ground. ${ }^{124}$ The renewed emphasis on protection of workers' rights and fair competition was confirmed by Jean-Claude Juncker in his State of the Union address on 14 September 2016 where he stated that 'workers should

\footnotetext{
120 Individual Member State opinions are available here: http://ec.europa.eu/dgs/secretariat_general/relations/relations_other/npo/index en.htm

$121 \mathrm{See}$ http://www.euractiv.com/section/social-europe-jobs/news/national-parliaments-invoke-yellow-cardin-response-to-revised-posted-workers-directive/. This is only the third time that such a procedure has been triggered.

122 http://www.politico.eu/wp-content/uploads/2016/05/3rd-yellow-card-V.Kreilinger.pdf.

123 Communication from the Commission to the European Parliament, the Council and the National Parliaments on the proposal for a Directive amending the Posting of Workers Directive, with regard to the principle of subsidiarity, in accordance with Protocol No 2 COM(2016) 55 final.

124 http://europa.eu/rapid/press-release_IP-16-2546_en.htm.
} 
get the same pay for the same work in the same place. Europe is not the Wild West, but a social market economy., 125

The use of the Subsidiarity Control Mechanism in this case (and predominantly by one regional bloc) highlights serious divisions across Europe and is indicative of the tensions between economic and social rights which came to the fore in the Laval case. On 3 July 2016, then French Prime Minister, Manuel Valls, threatened to stop applying the PWD unless the revised Directive is adopted. ${ }^{126}$ For home Member States, especially those from Central and Eastern Europe, the 'process of [relocation by enterprises], and that of the related migration of some of their workers to the old Member States, are the means by which convergence on Western European levels of productivity and per capita income are achieved. ${ }^{127}$ However, in light of current EU labour market conditions, including wage differentials and diversity of wage-setting regimes, in the context of an enlarged European Union, the balance struck by the PWD to establish a climate of fair competition and protect workers' rights while also promoting the transnational provision of services has changed considerably. Following the recent European enlargements, the ratio of highest to lowest national median wages across the EU has increased substantially and there are certainly valid suggestions that the way in which people move across the EU has changed. There has been a shift from the regular freedom of workers to move to another member state towards other mobility channels such as posting and/or (bogus) self-employment. ${ }^{128}$ According to Cremers, 'posting has become one of the channels for the cross-border recruitment of "cheap" labour without reference to the rights that can be derived from EU law on genuine labour mobility. ${ }^{129}$ Instead, under the current system of regulation 'posted workers may undercut the minimum conditions established by the host country's law or negotiated under generally applicable collective agreements and undermine the organization and functioning of local or sectoral labour markets. ${ }^{130}$ However, if posting of workers is to become a genuinely alternative mobility channel to the free movement of workers, then it must be subject to proper regulation, monitoring and enforcement. In its current form, the PWD is not, in many cases, able to adequately fulfil its own objectives and it is therefore unsuccessful in europeanising the applicability of national labour law systems. For host Member States, the absence of an equal pay principle, the requirement for the universal applicability of collective agreements, and the lack of clarity over minimum rates of pay lead to 'a concentration of posted workers in the lower echelons of labour markets [which] bears the risk of an erosion of labour standards and evasion of mandatory rules. This type of regime shopping leads to serious risks, such as the distortion of competition and a downward pressure on pay, ${ }^{131}$; which go directly against the PWD's objectives. The Commission's proposals for a revision of the PWD go some way towards alleviating some of these concerns and rebalancing the objectives of the Directive. However, it remains to be seen whether the proposals will be adopted in the face of substantial opposition from a number of Member States.

\footnotetext{
125 http://europa.eu/rapid/press-release_IP-16-3042_en.htm.

126 The Economist, Going posted, 9 July 2016.

127 N Adnett and S Hardy, The European Social Model - Modernisation or Evolution? (Elgar, 2005), p 201.

128 See note 3 above, $\mathrm{p} 4$.

129 See Cremers, note 61 above, p 157.

130 Ibid.

131 Ibid.
} 


\section{CONCLUSION}

The phenomenon of posted work is on the rise across the EU and is part of a broader trend whereby workers are increasingly making use of different mobility channels in order to move from one Member State to another. The PWD aims to europeanise the applicability of national labour law systems by promoting the transnational provision of services while also providing a climate of fair competition and ensuring respect for the rights of workers. The balancing of these objectives has led to tensions which culminated in the CJEU's decision in Laval where the Court firmly tilted the balance towards the protection of the transnational provision of services, and away from concerns for the rights of (posted) workers. Twenty years after its adoption, and in the context of an enlarged European Union, it is clear that the PWD is no longer able to adequately fulfil its objectives, and it therefore stands as an unsuccessful attempt at the europeanisation of the applicability of national labour law systems. The lack of clarity on the definition of minimum rates of pay and the absence of an equal treatment principle - inherent in the free movement of workers but not granted to posted workers who are regulated under the umbrella of free movement of services - has led to differentiated rules on wages across Member States. This has, as an unintended consequence, the effect of entrenching inequality on the basis of skill levels across the EU. Although appearing gender neutral, the PWD also does little to encourage 'substantive' equality between male and female posted workers and seems, instead, to undermine the principle of equal pay for work of equal value. In effect, the PWD's provisions, as interpreted by the CJEU, give posting companies from low wage countries a competitive advantage over companies in host Member States with high wages which goes beyond 'fair competition'. This may lead to a downward spiral of wage and labour cost competition which has a negative impact on local workers and risks destabilising coordinated wage-setting regimes. Equally, the PWD fails to protect those workers' rights which it has set out as essential within its provisions. Attempts to amend the PWD have hitherto been unsuccessful. The Commission's most recent proposal is certainly a step in the right direction however it is limited in its potential due to the legal base and the continued way in which it attempts to europeanise the applicability of national labour law systems. 